\title{
Publishing In The Accounting Journals: Is There A Gender Bias?
}

Kathryn M. Kimery (E-mail: k.kimery@stmarys.ca), St. Mary’s University, Halifax, Nova Scotia, Canada

Mark J. Mellon (E-mail: mmellon@unbsj.ca), University of New Brunswick Saint John, Canada

Shelley M. Rinehart (E-mail: Rinehart@unbsj.ca), University of New Brunswick Saint John, Canada

\begin{abstract}
To publish or not to publish? ... that is the question (adapted from William Shakespeare). In the world of academe, the answer is short and sweet... publish or get out. This rule holds true for both male and female faculty members, yet it is sometimes postulated that there may be some inconsistencies on how this rule applies across the genders. This study focuses on whether male and female accounting academics have distinctive patterns of representation as authors in top ranked accounting journals. Archival data, consisting of author information and article information was collected for two journals, The Accounting Review and Journal Accounting Research. Consistent with previous research findings, preliminary results suggest that females represent a disproportionately small minority of authors in both of these two top accounting journals.
\end{abstract}

\section{Introduction}

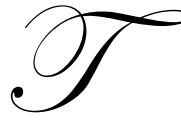

o publish or not to publish?... that is the question (adapted from William Shakespeare). In the world of accounting academe, the answer is short and sweet, publish or get out. Within academic circles never has this mantra been more apropos. From a holistic viewpoint, the daily life of an academic is comprised of certain functions, the most prominent of which are; the dissemination of knowledge, teaching, and service. The focus of this paper will invoke an atomistic viewpoint in examining academic success, by exploring the effect of publication success has on academic careers. An academic may well be forgiven for being a poor teacher but a lack of research output for an academic is not forgivable. In fact, sparse research productivity will most definitely have a deleterious effect on promotion and tenure outcomes.

Female participation in undergraduate and graduate programs has increased during the past several decades but this trend has yet to significantly impact gender distribution among the ranks of academia. Within university confines female academics tend to be concentrated in the junior ranks of academia, mainly being employed as instructors/lecturers or assistant professors. Meanwhile, males continue to dominate the more senior academic positions of associate professor and full professor. Is this situation one that will be corrected in short order as time allows for junior female faculty members to be promoted through the ranks? The answer seems somewhat uncertain. Surveys performed by the U.S. Department of Education indicate that the gap is shrinking, however slowly that movement may be. This study examines the comparable change in academic publishing rates as they break down across genders; the what, the why and the will be.

\section{Purpose}

In various studies of gender effects on academic careers, gender has been shown to have an impact on individual offers of employment (Koplin \& Singell 1996), promotion assessment (Bentley and Black 1992; Luzzader \& MacFarlane 2000; Winkler 2000) and publication success (Davis \& Astin 1990; Kolpin \& Singell 1996) across a variety of disciplines. The purpose of this research project is to examine patterns of authorship across several academic business disciplines. This study focuses on whether or not male and female academics have distinctive patterns of participation in academic publishing. This project examines trends in authorship over the past 25 years in 
two top accounting journals. Of particular interest, are gendered trends in authorship and publication patterns as they relate to factors such as time, discipline, academic rank, type of research, and propensity to collaborate.

\section{Literature Review}

A variety of reasons exist that may explain a documented discrepancy in academic publishing rates based on gender: 1) a gender bias across faculties; 2) a lack of mentorship opportunities for new female professors resulting from this bias; 3 ) the existence of an "old boys network mentality" with respect to editorial boards which in turn influence review panels and the tendency to submit; 4) a tendency to publish in lower ranked or non-academic journals; 5) the lack of an administrative culture where publication activity is valued.

Across virtually all disciplines, female participation in undergraduate and graduate programs has increased during the past several decades (West 1999). Specifically looking at Ph.D. program graduates, in 1981, approximately 35 percent of individuals awarded doctorates from U.S. universities were female. By 1996, this number had increased to more than 47 percent, an increase of almost eight percentage points over a 15-year period (West 1999). The growing proportion of female students in universities and the increase in female graduation from doctoral programs has not translated into comparable increases in the appointment and promotion of female on faculties at U.S. colleges and universities. In 1981, women held approximately 27 percent of all full time faculty appointments (tenure-track and non-tenure track) in the United States. Fifteen years later, that number had increased to only 33 percent despite the fact that 47 percent of all Ph.D.s awarded that year were to women (West, 1999). As Table 1 illustrates, by 1999 this percentage had increased to 36 percent with regard to all disciplines but only to 31 percent for accounting. In general terms the gap does appear to be narrowing, however, the transition is a slow one. Accounting seems to be lagging behind other disciplines in narrowing the gender gap, but further historical data would be necessary to thoroughly analyze the situation.

Table 1: Gender Composition of U.S. University Faculty

\begin{tabular}{|l|c|c|}
\hline & Female (Percentage of Total Faculty) & Male (Percentage of Total Faculty) \\
\hline All Disciplines & $36.3 \%$ & $63.7 \%$ \\
\hline Accounting & $30.9 \%$ & $69.1 \%$ \\
\hline
\end{tabular}

Source: U.S. Department of Education (1999)

Perhaps an issue of greater concern, and impact, is the distribution of faculty across ranks based on gender. As illustrated in Table 2, female faculty continue to be constrained to the lower levels of academia. In 1995, the largest contingent of females was in lecturer/instructor positions. This is in marked contrast with males where the largest cluster was found in the full professor rank. This situation changed slightly between 1995 and 1999. In 1999, the largest grouping of female faculty had shifted to the rank of assistant professor. Interestingly, there has been a decline in the percentage of women faculty categorized as lecturers and an increase in the number in the full professor rank. Male faculty still continue to be found predominantly in associate and full professor positions. While this data does suggest that as women continue in academia they are being promoted through the ranks, a more detailed analysis over a longer time frame comparing like cohorts of male and female faculty members would be necessary to draw any true conclusions in this respect.

Table 2: Gender Composition Of U.S. Faculty Positions By Rank

\begin{tabular}{|l|c|c|c|c|}
\hline Rank & $\begin{array}{c}\text { Percentage of } \\
\text { Female Faculty } \\
\text { in 1995 }\end{array}$ & $\begin{array}{c}\text { Percentage of } \\
\text { Male Faculty in } \\
\mathbf{1 9 9 5}\end{array}$ & $\begin{array}{c}\text { Percentage of } \\
\text { Female Faculty } \\
\text { in 1999 }\end{array}$ & $\begin{array}{c}\text { Percentage of } \\
\text { Male Faculty in } \\
\mathbf{1 9 9 9}\end{array}$ \\
\hline Lecturer/Instructor & $35 \%$ & $20 \%$ & $23 \%$ & $12 \%$ \\
\hline Assistant Professor & $30 \%$ & $20 \%$ & $28 \%$ & $19 \%$ \\
\hline Associate Professor & $21 \%$ & $24 \%$ & $22 \%$ & $24 \%$ \\
\hline Full Professor & $15 \%$ & $36 \%$ & $18 \%$ & $38 \%$ \\
\hline
\end{tabular}

Source: U.S. Department of Education $(1995,1999)$ 
Table 3 reinforces certain assumptions that were made with respect to Table 1 in that the accounting discipline seems to be out of sync with other disciplines in terms of gender distribution across academic ranks. The greatest concentration of female accounting faculty in the accounting discipline is lecturers/instructors, whereas males continue to dominate the higher ranking positions, being employed as associate and full professors. Of interest is that the second highest composition of females by rank is found in the associate professor category. A much higher percentage of accounting female faculty is found to hold the position of associate professor than is true for faculty positions in general. One wonders if this is truly a positive sign for female accounting faculty or if it merely indicates the lack of female accounting professors filling senior academic ranks. As indicated in Table 2, 18 percent of female faculty across all university disciplines are full professors. This is in stark contrast with accounting where only ten percent of female faculty are full professors. Once again, accounting seems to be lagging behind other disciplines in narrowing the gender gap.

Table 3: Gender Composition Of U.S. Accounting Faculty Positions By Rank

\begin{tabular}{|l|c|c|}
\hline & $\begin{array}{c}\text { Percentage of } \\
\text { Female Faculty in 1999 }\end{array}$ & $\begin{array}{c}\text { Percentage of } \\
\text { Male Faculty in 1999 }\end{array}$ \\
\hline No rank or other rank & $6 \%$ & $4 \%$ \\
Lecturer/Instructor & $30 \%$ & $21 \%$ \\
Assistant Professor & $25 \%$ & $21 \%$ \\
Associate Professor & $29 \%$ & $25 \%$ \\
Full Professor & $10 \%$ & $29 \%$ \\
\hline
\end{tabular}

Source: U.S. Department of Education (1999)

Apprenticeship of young researchers generally begins in the Ph.D. program, and it is well accepted that collaboration between doctoral students and their faculty advisors and supervisors is a beneficial first step toward future research and publishing success. It is at this early stage of an academic career that research streams are often defined and research collaboration networks established. Research shows that in general, recent male Ph.D. graduates are more likely to co-author published articles with their faculty supervisors, than are their female counterparts (Seagram, Gould, \& Pike 1998; Davis \& Patterson 2001). A limiting factor for females may be the reward systems in effect for doctoral students. Wong \& Sanders (1983) found that women were more likely to receive fellowships than were males but that males were more likely to be awarded with research assistantships. Fellowships may have encouraged females to pursue their academic studies while research assistantships may have encouraged, or required, their male counterparts to become more research active, whether for themselves or others.

Low representation of women on university faculties may be effectively self-limiting. Low numbers of women on faculty may contribute to chilly and unsatisfactory work environments, which lead to high turnover among female faculty and poor recruitment of new females to the faculty. Cullen and Luna (1993) cite the "Queen Bee" syndrome as another problem for female faculty growth and the paucity of senior female faculty members in academe. The "Queen Bee" syndrome describes a situation in departments with very few senior women faculty. These faculty members may feel defensive of their status in the department and act out this defensive by being overly competitive with newer female faculty members. Cullen and Luna (1993) believe that the tendency for some high-status female faculty members to engage in overly competitive behaviors lessens their ability to mentor, protect, and encourage newer female faculty member in their departments or disciplines. Davis and Astin (1990) suggest that women faculty members, especially single women without a male partner, are more likely to be excluded from the academic "old boys' club" (p. 99) and, therefore, miss out on the collegiality and networking that builds satisfying work experiences and successful careers. As a result more females may opt out of academic career paths. Kolpin \& Singel (1996) found that economics departments that were highest ranked on a measure of scholarly publications were the least likely to hire females. They also found that women were more likely to be hired in less research intensive departments, thus decreasing their chances for collaboration and mentorship with established researchers. 
While some suggest that gender differences in research productivity are small or insignificant (Robinson 1973; Reskin 1977), an overwhelming body of research demonstrates that female academics tend to have less productive research and publication records than do male academics (Converse \& Converse 1971; Cole \& Cole 1973; Astin \& Bayer 1979; Davis \& Astin 1990; Kolpin \& Singell 1996). This trend appears to be consistent across countries--the United States (Davis \& Astin 1990), Canada (Nakhaie 2002) and Norway (Lie 1990; Kyvik 1990)--and also across disciplines--science (Nakhaie 2002), economics (Davis \& Patterson 2001), and political science (Converse \& Converse 1971). If lower research productivity among women faculty members does in fact exist, it may explain, in part, the relatively small number of women on university tenure-track faculties, at least, at high-status, research-focused universities. Women are disproportionately concentrated not only at lower ranks within universities, but are also on the faculties of smaller, less-prestigious colleges and universities (U.S. Department of Education 1995). In their study comparing behaviors and achievements of highly productive faculty of both sexes, Davis and Astin (1990) find that even among equally productive, high-performing faculty researchers, females are still more likely to be on the faculties of less prestigious institutions than are males. Davis and Astin (1990) conclude that “...women's lower productivity may be as much the effect as the cause of their institutional 'ghettoization' (p. 95)".

Inherent in any consideration of publication productivity for male and female faculty members is recognition of the important role that academic journals play in the professional lives of these academics as well as the health and long-term development of the disciplines themselves. Academic journals, via publishing choices made by their editors and editorial boards, fulfill two critical gatekeeper roles: 1) they screen, validate and disseminate new knowledge in their respective fields; and 2) they validate competence and provide the means for career advancement and status for those authors they choose to publish. This dual function is described by Hargens (1988, p. 139 ) as "...both a means by which a community certifies additions to its body of accepted knowledge and a means through which individual scientists compete for priority and recognition." As a result, much can be gained by spotlighting patterns that emerge in the articles and authors who are deemed worthy for inclusion in the key journals of a specific discipline.

In the world of academia, a professor's duties are comprised of teaching, research, and service. While the majority of academic institutions may not publicly be willing to express the viewpoint that good research output can compensate for poor teaching, research does tend to support that very fact. Street, Baril, and Benke (1993) found that research intensive universities in the United States place twice the importance on research than on teaching when considering promoting faculty members. This was not the case for teaching oriented universities where a more balanced support for both teaching and research activities was found. A survey of Canadian Universities found results similar to the study of American research oriented Universities (Bedard and Dodds 1994). As per Table 4, their research suggests that in Canadian Universities, research ranks twice as important as teaching when faculty members are being considered for promotion to Full Professor.

Table 4: Importance Placed On Duties For Promotional Assessments

\begin{tabular}{|l|c|c|c|}
\hline Promotion Under Consideration & Research & Teaching & Service \\
\hline From Assistant to Associate Professor & $58 \%$ & $32 \%$ & $9 \%$ \\
\hline From Associate to Full Professor & $60 \%$ & $28 \%$ & $12 \%$ \\
\hline
\end{tabular}

Source: Bedard \& Dodds (1994)

\section{Methodology}

Content analysis was the primary analytical tool used in this study. Two journals were chosen as representing the top academic publication outlets for the accounting discipline; The Accounting Review and The Journal of Accounting Research. A total of 2046 articles from 188 issues were coded representing over 25 years of publication activity in accounting (See Table 5). Each article was assessed in terms of author information (gender, rank, affiliation, order in author list) and article information (page length and empirical orientation). Each issue was assessed in terms of editorial board, reviewer lists and the number of articles. A sample of the coding sheets used can be found in Appendix A of this paper. 
Table 5: Coded Journals

\begin{tabular}{|l|c|c|c|}
\hline Journal Title & Years Coded & $\begin{array}{c}\text { Number of } \\
\text { Issues Coded }\end{array}$ & $\begin{array}{c}\text { Number of } \\
\text { Articles Coded }\end{array}$ \\
\hline Journal of Accounting Research & $1978-2002$ & 76 & 860 \\
\hline The Accounting Review & $1975-2002$ & 112 & 1186 \\
\hline Total & & 188 & 2046 \\
\hline
\end{tabular}

\section{Preliminary Descriptive Results}

In 1999, thirty one percent of accounting academics were female. A full 65 percent of these female academics were ranked at or below the assistant professor level. Two arguments can be made here; first that the high percentage of individuals in the non-research oriented ranks (instructors) would have a negative impact on publishing activity; or conversely the overwhelmingly high percentage of assistant and associate faculty members aspiring to become full professors would have a positive impact on publication output. Interestingly support was found for both. There does appear to be a lower propensity for females to publish (Table 6). While some of this can be explained by differences in the sheer numbers of male and female faculty members, the distributions do not match. Where we see a 70:30 split between male and female accounting faculty, we see an 85:15 split over the past 25 years of journal activity (Table 6). In fact, when we look at smaller cross sections of years, we see at best an 80:20 split tween male and female authors of academic accounting papers (Table 7). What does this tell us? Despite the narrowing of the gap in faculty representation, females continue to experience less publication success than one would expect based on faculty numbers. However, they also continue to be more heavily represented in the instructor ranks where publication activity may not comprise a significant portion of their job requirements.

Table 6: Gender Authoring by Journal

\begin{tabular}{|l|c|c|c|c|}
\hline Journal/Discipline & $\begin{array}{c}\text { Male } \\
(\mathbf{1 9 7 8}-\mathbf{2 0 0 2})\end{array}$ & $\begin{array}{c}\text { Female } \\
(\mathbf{1 9 7 8}-\mathbf{2 0 0 2})\end{array}$ & $\begin{array}{c}\text { Unknown } \\
(\mathbf{1 9 7 8}-\mathbf{2 0 0 2})\end{array}$ & Total \\
\hline Journal of Accounting Research & $1332(87 \%)$ & $203(13 \%)$ & $2(0 \%)$ & 1537 \\
\hline The Accounting Review & $1469(86 \%)$ & $218(13 \%)$ & $24(1 \%)$ & 1711 \\
\hline \multicolumn{1}{|c|}{ Total } & $2801(86 \%)$ & $421(13 \%)$ & $26(1 \%)$ & 3248 \\
\hline
\end{tabular}

What is encouraging, however, is the fact that over the years female representation at the various faculty levels and in respected academic journals has experienced growth. An examination of publishing activity broken into 5 year cohorts suggests a continuous and stable improvement in academic authorship rates for female faculty members. While not yet approaching the 1999 ratio of male to female faculty members, we have seen female publication rates increase from 5 percent to 21 percent between 1978 and 2002 . However, accounting continues to be a male dominated discipline with male:female ratios exceeding overall discipline averages (Table 1).

Table 7: Gender Authoring Over Five Year Periods

\begin{tabular}{|c|c|r|r|c|}
\hline Years & Male & Female & Unknown & Total \\
\hline $1978-1982$ & $684(93.2 \%)$ & $38(5.2 \%)$ & $12(1.6 \%)$ & $734(100.0 \%)$ \\
\hline $1983-1987$ & $674(90.8 \%)$ & $63(8.5 \%)$ & $5(0.7 \%)$ & $742(100.0 \%)$ \\
\hline $1988-1992$ & $486(85.7 \%)$ & $77(13.6 \%)$ & $4(0.7 \%)$ & $567(100.0 \%)$ \\
\hline $1993-1997$ & $454(80.8 \%)$ & $108(19.2 \%)$ & $0(0.0 \%)$ & $562(100.0 \%)$ \\
\hline $1998-2002$ & $503(78.2 \%)$ & $135(21.0 \%)$ & $5(0.8 \%)$ & $643(100.0 \%)$ \\
\hline $1978-2002$ & $2801(86.2 \%)$ & $421(13.0 \%)$ & $26(0.8 \%)$ & $3248(100.0 \%)$ \\
\hline
\end{tabular}




\section{Discussion}

The glass ceiling in academia continues to skew the distribution of male and female academics across disciplines and across academic ranks. We continue to see high concentrations of female academics in non-research and junior academic ranks while their male counterparts hold senior academic positions purportedly in "better" schools. That is to say that research oriented institutions tend to hire men. Research suggests that this trend may be set as early as the beginning of grad studies where more males than females are offered graduate research assistantships as opposed to teaching or scholarship related monies.

What does this mean for the academe? In the day of equal opportunity and employment equity the accounting profession and discipline is leaving itself open for criticism. Not only does the discipline exhibit trends similar to academe in general, in fact analysis of the discipline reveals an even more disparate distribution than one might expect. This is an issue that must be addressed and soon.

\section{Next Steps}

The preliminary results reported in this paper are part of a larger database of accounting journal information. Further data analysis investigating frequency of co-authorship, authorship citation placement, faculty rank and editorial board characteristics is in order. A comparison of findings across other business, and even non business, related disciplines would also be of value and interest to the academic community. If such discrepancies exist it is crucial for us to answer "why" these differences can be observed and what we can do to lessen the gap in the future. Is it simply a matter of implementing support mechanisms such as more assistantships, better and more clearly articulated mentorship programs, administration that is supportive of fostering an inclusive research culture and a hiring and promotion system that recognizes the short comings and moves to address them.

\section{References}

1. Astin, H.S., \& Bayer, A.E. (1979). "Pervasive Sex Differences in the Academic Reward System: Scholarship, Marriage, and What Else?", in Academic Rewards, D.R. Lewis \& W.E. Becker, Jr. (eds.), Cambridge, MA: Ballinger Publishing.

2. Bedard, J., \& Dodds, C. (1994) "The University Professoriate in Canada", Contemporary Accounting Research, Special Education Research Issue, 75-109.

3. Benedict, Mary Ellen \& Wilder, Lisa. (1999). "Unionization and Tenure and Rank Outcomes in Ohio Universities", Journal of Labor Research, 20 (2), 185-201.

4. Bentley, R.J. \& Black, R.T. (1992). “Two Decades of Gains of Gains for Female Faculty?”, Teachers College Record, 93 (4), 697-709.

5. Blank, R.M. (1991). "The Effects of Double-Blind Versus Single-Blind Reviewing: Experimental Evidence From the American Economic Review”, American Economic Review, 81(5), 1041-1068.

6. Bronstein, Phyllis; Black, Leora; Pfennig, Joyce; \& White, Adele. (1986). "Getting Academic Jobs: Are Women Equally Qualified - And Equally Successful?”, American Psychologist, 318-321.

7. Cole, J.R. \& Cole, S. (1973). Social Stratification in Science, Chicago: University of Chicago Press.

8. Converse, P.E., \& Converse, J.M. (1971). "The Status of Women as Students and Professionals in Political Science", Political Science, 4, pp. 328-348.

9. Cullen, Deborah L. and Luna, Gaye. (1993). "Women Mentoring in Academe: Addressing the Gender Gap in Higher Education", Gender and Education, 5 (2), 125-137.

10. Davis, D.E., \& Astin, H.S. (1990). "Life Cycle, Career Patterns and Gender Stratification in Academe: Breaking Myths and Exposing Truths", in Storming the Tower: Women in the Academic World, S.S. Lie, \& V.E. O'Leary (ed.), New York: Nichols/GP Publishing, 87-107.

11. Davis, Joe C. \& Patterson, Debra Moore. (2001). "Determinants of Variations in Journal Publication Rates of Economists", American Economist, 45 (1), 86-91.

12. Ginther, Donna K. (2001). "Does Science Discriminate Against Women? Evidence From Academia, 19731997”, Working Paper Series (Federal Reserve Bank of Atlanta), 2001, Issue 2. 
13. Hargens, L.L. (1988). "Scholarly Consensus and Journal Rejection Rates", American Sociological Review, 53, 139- 51.

14. Kahn, Shulamit. (1993). "Gender Differences in Academic Career Paths of Economists", American Economic Review, 83 (2), 52-56.

15. Kolpin, Van W. \& Singell, Larry D. Jr. (1996). "The Gender Composition and Scholarly Performance of Economics Departments: A Test for Employment Discrimination”, Industrial and Labor Relations Review, 49 (3) , 408-423.

16. Kyvik 1990.

17. Lie, S.S. (1990). "The Juggling Act: Work and Family in Norway", in Storming the Tower: Women in the Academic World, S.S. Lie, \& V.E. O'Leary (ed.), New York: Nichols/GP Publishing, 108-128.

18. Luzzadder-Beach, Sheryl \& Macfarlane, Allison. (2000). "The Environment of Gender and Science: Status and Perspectives of Women and Men in Physical Geography", Professional Geographer, 52 (3), 407-424.

19. Massachusetts Institute of Technology. (1999). "Committees on Women Faculty in the School of Science, A Study on the Status of Women Faculty in Science at MIT", Available at http://web.mit.edu/fnl/women/women.html.

20. McDowell, John M. \& Smith Janet Kiholm. (1992). "The Effect of Gender-Sorting on Propensity to Coauthor: Implications for Academic Promotion”, Economic Inquiry, XXX (January), 68-82.

21. Misra, Joya; Kennelly, Ivy \& Karides, Marina. (1999). "Employment Chances in the Academic Job Market in Sociology: Do Race and Gender Matter?”, Sociological Perspectives, 42 (2), 215-247.

22. Nakhaie, M. Reza. (2002). "Gender Differences in Publication among University Professors in Canada". Canadian Review of Sociology \& Anthropology, 39 (2), 151-179.

23. Reskin, B. (1977). "Scientific Productivity and the Reward Structure of Science", American Sociological Review, 47, 491-504.

24. Seagram, Belinda Crawford; Gould, Judy \& Pyke Sandra W. (1998). "An Investigation of Gender and Other Variables on Time to Completion of Doctoral Degrees", Research in Higher Education, 39 (3), 319-335.

25. Street, Donna L., Baril, Charles P., \& Benke Jr., Ralph L. "Research, Teaching, and Service in Promotion and Tenure Decisions of Accounting Faculty", Journal of Accounting Education, 11 (1), 43-60.

26. Toren, N. (1990). "Would More Women Make a Difference? Academic Women in Israel", in Storming the Tower: Women in the Academic World, S.S. Lie, \& V.E. O'Leary (ed.), New York: Nichols/GP Publishing, 74-85.

27. U.S. Department of Education (1995). National Center For Education Statistics, Integrated Postsecondary Data System, Fall Staff Survey.

28. Wong, Herbert Y. \& Sanders, Jimy M. (1983). "Gender Differences in the Attainment of Doctorates", Sociological Perspectives. 26 (1), 29-50.

29. West, Martha S. (1995). "Women Faculty: Frozen in Time", Academe, 81 (Jul-Aug).

30. West, Martha S. (1999). "Women Faculty: Frozen in Time 1999", Available at http://www.stangesupport.org/bias/\#west.

31. Winkler, Julie A. (2000). "Faculty Reappointment, Tenure, and Promotion: Barriers for Women", Professional Geographer, 52 (4), 737-750. 
APPENDIX A

EDITORIAL CODE SHEET

REVISED CODE SHEET

GENDER OF AUTHORSHIP STUDY

EDITORIAL INFORMATION

1. JOURNAL TITLE:

Journal of Accounting Research

The Accounting Review

2. YEAR:

3. VOLUME:

4. NUMBER OF ARTICLES:

5. EDITOR:

$\begin{array}{ll}\text { Male } \\ \_ & \text {Female } \\ & \text { Unknown (record name and affiliation) }\end{array}$

6. EDITORIAL BOARD:

Male

_ Female

__ Unknown (record names and affiliations)
REFERENCE:

CODER: 
APPENDIX B

ARTICLE CODE SHEET

REVISED CODE SHEET

GENDER OF AUTHORSHIP STUDY

JOURNAL INFORMATION

$7 . \quad$ JOURNAL TITLE:

__01_ Journal of Accounting Research

__ 02 _ The Accounting Review

8. YEAR:

9. VOLUME:

10. ARTICLE NUMBER:

11. PAGE NUMBERS: __ two fields

12. TOTAL NUMBER OF PAGES:

13. NUMBER OF AUTHORS:

14. AUTHOR INFORMATION:

MALE: multiple records

\section{Rank:}

student assistant associate full other (please specify) Listed Alphabetically

FEMALE:

Rank:

student

assistant associate

full other (please specify) Listed Alphabetically

15. APPROACH:

Conceptual

Empirical

\section{Affiliation:}

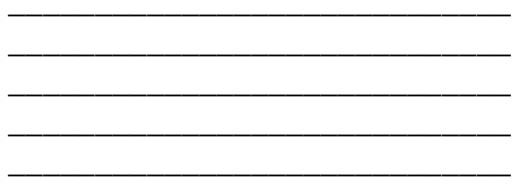

Affiliation:

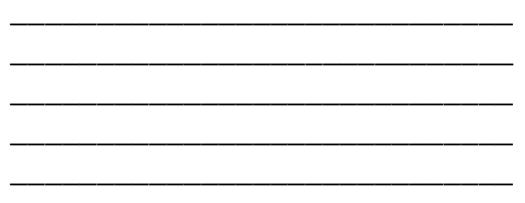

REFERENCE:

CODER:
Cite Position:

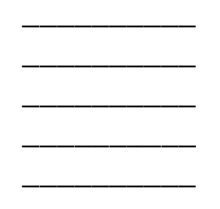

Cite Position:

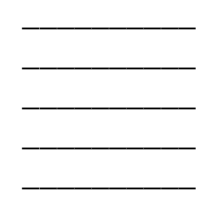




\section{APPENDIX C DATA DICTIONARY}

\section{INSTRUCTIONS}

Included in this code book you will find definitions of the categories to be used when coding the selected journal articles. The definitions are provided to you in the same order as they appear on the code sheet for ease of reference when coding. Also included are several examples of topics which fall under the various areas included in this study. These are included to further help you clarify primary topics of discussion in each article.

Your instructions for coding are as follows:

- REFERENCE - will be numbered in sequence by the researcher to identify separate records (i.e. Journal of Marketing JM1, JM2...., Journal of Marketing Research JMR1, JMR2...., MIS Quarterly MISQ1, MISQ2..., Academy of Management Review AMR1, AMR2....).

- CODER - Please place your initials in the top right hand corner of each code sheet.

- All categories are fully explained in the definition section of this code book.

- If you are unsure of a particular issue please make a detailed note so that the researchers will be able to address the problem at the end of the coding session.

- For every volume you will complete an Editorial coding sheet and a Journal coding sheet for every article within that volume.

\section{DEFINITIONS}

(JOURNAL INFORMATION)

1. JOURNAL TITLE: check the title of the journal you are coding

2. YEAR: record the year that the journal you are coding was published

3. VOLUME: record the volume, including the issue number, of the journal you are coding [i.e. 37(4)].

4. ARTICLE NUMBER: record the placement of the article within the volume (i.e. 5/10).

5. PAGE NUMBERS: record the start page and end page of the article you are coding.

6. TOTAL NUMBER OF PAGES: record the total number of pages in the article.

\section{AUTHOR INFORMATION:}

Record the number of female and male authors of the article you are coding

For each gender record the number of authors falling into each rank category (this is provided on the first page of the article).

Record the school/business affiliation for each of the authors.

Record the position of each author's position in the list of authors on the title page of the article (if they are cited alphabetically and/or have a statement of equal contribution make note of it)

Record the names, rank, affiliation and cite positions of individuals whose gender you are unsure of for follow-up

8. APPROACH: record whether or not the article follows a conceptual or empirical methodology

Conceptual - based on a review of the literature, no data collection

Empirical - data has been collected and statistically analyzed. 


\section{DEFINITIONS}

(EDITORIAL INFORMATION)

- REFERENCE - will be numbered in sequence by the researcher to identify separate records (i.e. Journal of Marketing JM1, JM2...., Journal of Marketing Research JMR1, JMR2..., MIS Quarterly MISQ1, MISQ2..., Academy of Management Review AMR1, AMR2....).

- CODER - Please place your initials in the top right hand corner of each code sheet.

1. JOURNAL TITLE: check the title of the journal you are coding

2. YEAR: record the year that the journal you are coding was published

3. VOLUME: record the volume, including the issue number, of the journal you are coding [i.e. 37(4)].

4. NUMBER OF ARTICLES: record the total number of articles included in the journal you are coding (do not include book reviews and editorial pieces).

5. EDITOR: record the gender of the editor, if unknown record the individual=s name and affiliation for follow-up).

6. EDITORIAL BOARD: record the number of males and the number of females listed as serving on the editorial review board (record the names and affiliations of individuals whose gender you are unsure of for followup).

Notes 
Notes 